\title{
A tale of twists: loperamide-induced torsades de pointes and ventricular tachycardia storm
}

\author{
Kamal Kant Sahu @e, ${ }^{1}$ Amr El Meligy, ${ }^{2}$ Ajay Kumar Mishra, ${ }^{1}$ Sanjeev Goyal ${ }^{2}$
}

${ }^{1}$ Department of Internal Medicine, Saint Vincent Hospital, Worcester, Massachusetts, USA ${ }^{2}$ Division of Cardiology, Saint Vincent Hospital, Worcester, Massachusetts, USA

\section{Correspondence to} Dr Kamal Kant Sahu; drkksahu85@gmail.com

Accepted 20 January 2020

\section{DESCRIPTION}

A 69-year-old man with past medical history of coronary artery disease, status postcoronary artery bypass, ischaemic cardiomyopathy with ejection fraction of $15 \%$, status postautomatic implantable cardioverter defibrillator since 2013, known case of ventricular tachycardia (VT), on sotalol, irritable bowel syndrome (IBS) on loperamide as needed, chronic kidney disease, stage III was brought to emergency room for a syncopal event. His ECG rhythm was as shown in figure 1A,B. ECG showed prolonged QTc interval with a continuously varying QRS complex morphology, which was suggestive of torsade de pointes (TdP). TdP can have either an inherited or an acquired cause. In our case, patient was taking sotalol; however, the dose was reduced from $80 \mathrm{mg}$ two times per day to once daily 3 weeks ago in view of worsening renal functions. However, he was also taking $100 \mathrm{mg}$ of loperamide, 2 tablets every day for last 7 days for his IBS. His laboratory tests on presentation showed $\mathrm{Na}^{+}$ $140 \mathrm{mmol} / \mathrm{L}, \mathrm{K}^{+} 4.2 \mathrm{mmol} / \mathrm{L}, \mathrm{Ca}^{+} 8.5 \mathrm{mg} / \mathrm{dL}, \mathrm{Mg}^{+}$ $2.2 \mathrm{mg} / \mathrm{dL}$ and $\mathrm{PO}^{+} 3.5 \mathrm{mg} / \mathrm{dL}$. With previous history of arrythmias, a recent loperamide use and normal electrolytes, we postulated that the patient's QTc prolongation and subsequent $\mathrm{TdP}$ were due to loperamide toxicity.

Implantable cardioverter defibrillator (ICD) interrogation showed that he received 29 antitachycardia pacing deliveries and 25 shock deliveries in last few days, with more than three events in a 24-hour span, which fulfilled the criteria for VT storm in this case (figure $2 \mathrm{~A}-\mathrm{C}$ ).

$\mathrm{TdP}$ is mostly caused by drugs and dyselectrolytemia, which can cause excessive increase of the QT interval. Loperamide is a well-known overthe-counter (OTC) antidiarrheal agent, which is increasingly being used by drug abusers to improve opioid withdrawal symptoms. ${ }^{1}$ More importantly, if patient is also taking an opioid detoxifying medication, methadone, it can promote development of $\mathrm{TdP} / \mathrm{VT}^{2}{ }^{3} \mathrm{VT}$ storm is a lethal syndrome that is defined as three or more sustained episodes of VT, or appropriate ICD shocks during a 24-hour period. In our patient, we tried over drive pacing to shorten his QT interval to which he did not respond.

Subsequently, he was started on tablet mexiletine $200 \mathrm{mg}$ three times per day and his single chamber ICD was replaced with dual chamber ICD. Since then, patient is $\mathrm{V}$-paced with no more episodes of VT (figure 2D).

The current literature suggests that neither the cumulative ingested dose nor the loperamide drug level in the serum can predict the likelihood to

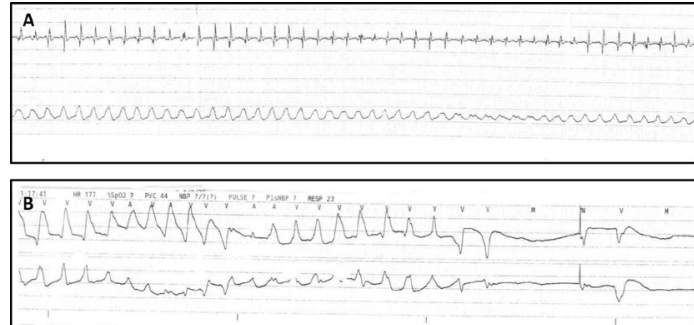

Figure $1 \quad(A, B)$ ECG shows prolonged QTc interval with a continuously varying QRS complex morphology, which is suggestive of torsade de pointes.

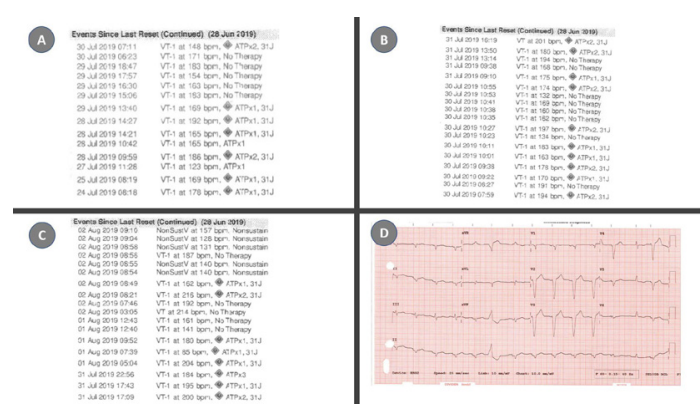

Figure 2 (A-C) Implantable cardioverter defibrillator (ICD) interrogation data confirming ventricular tachycardia storm. (D) Rhythm reverted to sinus, post-ICD shock.

develop loperamide-related cardiotoxicity. The only other reported case of loperamide-induced VT storm (with normal QT interval) was due to intentional overdose of $400 \mathrm{mg}$ in 24 hours. ${ }^{4}$ Our case consumed $200 \mathrm{mg} /$ day for 7 days and also had $\mathrm{TdP}$ in addition to VT storm. A recent review on the electrocardiographic changes in loperamide toxicity was done by Teigeler et al..$^{5}$ The review had 36 cases with median dose of loperamide 200 mg (134-400 mg), median QTc interval $620 \mathrm{~ms}$ (565-701 ms) and VT was experienced by $24 / 36$ (67\%) of patients. Timely diagnosis and appropriate intervention can be helpful in preventing fatality in many electrophysiological perturbations and other cardiac conditions. ${ }^{6} 7$ Our case

\section{Learning points}

- Torsade de pointes and ventricular tachycardia (VT) storm are extremely lethal conditions and need urgent intervention.

- Definitive causes and toxicities if found can help in preventing further episodes of VT storm. 
highlights importance of reviewing medication list, especially the OTC drugs like loperamide and challenges in the management of VT.

Contributors KKS: case management and draft. AEM: manuscript writing and editing. AM: ECG reading and review. SG: management and review.

Funding The authors have not declared a specific grant for this research from any funding agency in the public, commercial or not-for-profit sectors.

Competing interests None declared.

Patient consent for publication Obtained.

Provenance and peer review Not commissioned; externally peer reviewed.

\section{ORCID iD}

Kamal Kant Sahu http://orcid.org/0000-0002-0382-6882

\section{REFERENCES}

1 Katz KD, Cannon RD, Cook MD, et al. Loperamide-Induced torsades de pointes: a case series. J Emerg Med 2017:53:339-44.

2 Krantz MJ, Kutinsky IB, Robertson AD, et al. Dose-Related effects of methadone on QT prolongation in a series of patients with torsade de pointes. Pharmacotherapy 2003:23:802-5.

3 Mishra AK, Sahu KK, Lal A. Significance of prolonged PR interval in infections. QJM 2019:35.

4 Al-khatib J, Vindhyal SR, Boppana VS, et al. Ventricular tachycardia storm induced by loperamide abuse. Cureus 2019:11:e3981.

5 Teigeler T, Stahura H, Alimohammad R, et al. Electrocardiographic changes in loperamide toxicity: case report and review of literature. J Cardiovasc Electrophysiol 2019:30:2618-26

6 Sahu K, Mishra A, Lal A, et al. An interesting case of expressive aphasia: Enterococcus faecalis related infective endocarditis complicating as septic emboli. QJM 2019:pii: hcz169.

7 Mishra AK, Sahu KK, Lal A. Significance of prolonged PR interval in infections. QJM 2019:pii: hcz192.

Copyright 2020 BMJ Publishing Group. All rights reserved. For permission to reuse any of this content visit

https://www.bmj.com/company/products-services/rights-and-licensing/permissions/

BMJ Case Report Fellows may re-use this article for personal use and teaching without any further permission.

Become a Fellow of BMJ Case Reports today and you can:

- Submit as many cases as you like

- Enjoy fast sympathetic peer review and rapid publication of accepted articles

- Access all the published articles

Re-use any of the published material for personal use and teaching without further permission

\section{Customer Service}

If you have any further queries about your subscription, please contact our customer services team on +44 (0) 2071111105 or via email at support@bmj.com.

Visit casereports.bmj.com for more articles like this and to become a Fellow 